\begin{tabular}{l|l|l|} 
CRITICAL & $\begin{array}{l}\text { Western Ghats } \\
\text { PARTNERSHIP FUND }\end{array}$ & Special Series \\
\hline
\end{tabular}

\title{
BACK FROM OBSCURITY: NOTES ON THE CURRENT DISTRIBUTION, THREATS AND CONSERVATION STATUS OF A POORLY KNOWN CYPRINID, HYPSELOBARBUS LITHOPIDOS (DAY, 1874) FROM THE WESTERN GHATS OF INDIA
}

\author{
Anvar Ali ${ }^{1}$, Siby Philip ${ }^{2}$ \& Rajeev Raghavan ${ }^{3}$ \\ 1,2,3 Conservation Research Group (CRG), St. Albert's College, Kochi, Kerala 682018, India \\ ${ }^{2}$ Department of Zoology, Nirmalagiri College, Koothuparamba, Kerala 670701, India \\ ${ }^{3}$ Zoo Outreach Organization (ZOO), 96 Kumudham Nagar, Vilankurichi Road, Coimbatore, Tamil Nadu 641035, India \\ ${ }^{1}$ anvaraliif@gmail.com, ${ }^{2}$ philipsiby@gmail.com, ${ }^{3}$ rajeevraq@hotmail.com (corresponding author)
}

\begin{abstract}
Hypselobarbus lithopidos (Day, 1874) is a poorly known cyprinid fish endemic to the rivers of the Western Ghats of India. This species is assessed as Data Deficient in the IUCN Red List of Threatened Species with a note that it could be possibly extinct. Here, we provide information on a recent collection of this species from the type locality, and discuss its current distribution, ecology, threats and conservation. A revised Red List status for the species is also proposed.
\end{abstract}

Keywords: Canara barb, Endangered, Gonoproktopterus, Western Ghats.

DOI: http://dx.doi.org/10.11609/JoTT.03655.4743-51 | ZooBank: urn:Isid:zoobank.org:pub:AC9FED30-EE67-4203-BF7A-FF89150FBE0C

Editor: Anonymity requested.

Date of publication: 26 September 2013 (online \& print)

Manuscript details: Ms \# 03655 | Received 07 June 2013 | Final received 10 September 2013 | Finally accepted 11 September 2013

Citation: Ali, A., S. Philip \& R. Raghavan (2013). Back from obscurity: notes on the current distribution, threats and conservation status of a poorly known cyprinid, Hypselobarbus lithopidos (Day 1874) from the Western Ghats of India . Journal of Threatened Taxa 5(13): 4743-4751; http://dx.doi.org/10.11609/JoTT.03655.4743-51

Copyright: (c) Ali et al. 2013. Creative Commons Attribution 3.0 Unported License. JoTT allows unrestricted use of this article in any medium, reproduction and distribution by providing adequate credit to the authors and the source of publication.

Funding: Rajeev Raghavan thanks the Mohammed Bin Zayed Species Conservation Fund (MBZSCF; Project 1225670) and the North of England Zoological Society (NEZS), Chester Zoo for providing financial support for the project on the 'Lost fishes of Western Ghats'.

Competing Interest: The authors declare no competing interests. Funders had no role in study design, data collection, results interpretation and manuscript writing.

Author Contribution: AA collected the specimens. RR, AA and SP carried out the analysis. RR and SP wrote the text. RR is the Principal Investigator of the project from which the data originated.

Author Details: ANVAR Au interested in taxonomy and systematics of freshwater fishes of the Western Ghats. SIBY PHILIP is interested in molecular phylogenetics, evolution and biogeography of freshwater fishes of the South Asia region. RAJEEV RAGHAVAN is interested in interdisciplinary research focused on generating information and developing methods to support conservation decision-making, especially in freshwater ecosystems

Acknowledgements: Rajeev Raghavan thanks Ralf Britz, Natural History Museum, London for his help with the examination of Day's materials, for photographs and useful discussions; Helmut Wellendorf, Natural History Museum, Vienna; Ronald de Ruiter, Naturalis, Leiden; Leo Smith and Kevin Swagel, Field Museum, Chicago; Rohan Pethiyagoda, Australian Museum, Sydney for information and photograph of the syntypes; Neelesh Dahanukar, IISER, Pune for help with relevant literature; J.D. Marcus Knight for useful discussions and Ambily Nair for her help and support. Local fishers in and around Sullia and Kasargod are thanked for the cooperation and help during the field work.
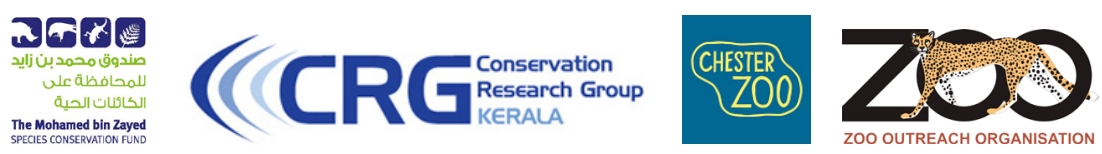

The publication of this article is supported by the Critical Ecosystem Partnership Fund (CEPF), a joint initiative of I'Agence Française de Développement, Conservation International, the European Commission, the Global Environment Facility, the Government of Japan, the MacArthur Foundation and the World Bank. 


\section{INTRODUCTION}

In his paper on 'Some new or little known fishes of India' published in the Proceedings of the Zoological Society of London, Francis Day (1874) described five new species of fish, one of which was Barbus (= Hypselobarbus) lithopidos, from South Canara (= Dakshina Kannada). The fish was known to attain up to 24 inches in length and was considered 'not uncommon' in rivers of the region (Day 1878, 1889). A specimen measuring 7.4 inches long was illustrated by Day (1878) in his book on the Fishes of India; being a natural history of the fishes known to inhabit the seas and fresh waters of India, Burma, and Ceylon.

From 1909 until 1975, several collections of $H$. lithopidos were made from the rivers of the southern part of the Western Ghats flowing through the states of Kerala and Karnataka (see table 1), after which there were no records of the species. The absence of $H$. lithopidos in collections from a region which has been the focus of several comprehensive field surveys (Easa \& Basha 1995; Chapgar \& Mankadan 2000; Kurup et al. 2004; Thomas 2004; Biju 2005) led to the assumption that the species might probably be extinct (see Raghavan \& Ali 2011).

Although several recent papers (Arunachalam et al. 2000; Vijaykumar et al. 2008; Ahmad et al. 2013; Vijaylaxmi \& Vijaykumar 2011; Arunachalam et al. 2012) mentioned collecting $H$. lithopidos, these need to be verified as no voucher specimens are available. Ahmad et al. (2013) listed H. lithopidos as occurring in Hariharapura in the Tunga drainage. However, one of the authors of the paper who was part of the Cypriniformes working group that evaluated the conservation status of the Hypselobarbus species from Western Ghats in 2010 for the IUCN Red List of Threatened Species did not provide this record, probably due to the lack of clarity in the species identification. There was also a general consensus within the working group that there are no validated records of this species since 1941 (see Raghavan \& Ali 2011).

Similarly, Arunachalam et al. (2012; pp. 70 and 71) in their revision of the genus Hypselobarbus records collecting $H$. lithopidos from the Shimoga fish farm and Rusewalai (= Rosemalai?) fish farm. They also provide illustrations for these materials (see figure $1 \mathrm{~A} \mathrm{p} 64$ and figure 3A p 66 of Arunachalam et al. 2012). However, these are clear misidentifications as the material illustrated in p 64 has a lateral line scale count of 30-31, while the material in $\mathrm{p} 66$ has a lateral line scale count of 34-36. Hypselobarbus lithopidos has a lateral line scale count of 37-39 (Day 1874; Knight et al. 2013; also see Table 2). Raghavan \& Ali (2011) also suggested that the record of $H$. lithopidos by Arunachalam et al. (2000) from Kal River in the Konkan region of Maharashtra requires verification. This suggestion might hold true as the record of $\mathrm{H}$. lithopidos from Kal River, did not find a mention in a recent paper by the same authors (Arunachalam et al. 2012).

Recently (Knight et al. 2013) re-discovered $H$. lithopidos based on collections from the Phalguni River in Dakshin Kannada District of Karnataka State, laying to rest the speculation that the species is extinct. As part of the on-going project on the 'lost fishes of Western Ghats', we obtained specimens of $\mathrm{H}$. lithopidos (Image 1) from an additional river system, part of the erstwhile South Canara region, its type locality. This paper serves to document this additional record, and discuss the current distribution, threats and conservation status of this species. We also propose a revised Red List status for $H$. lithopidos.

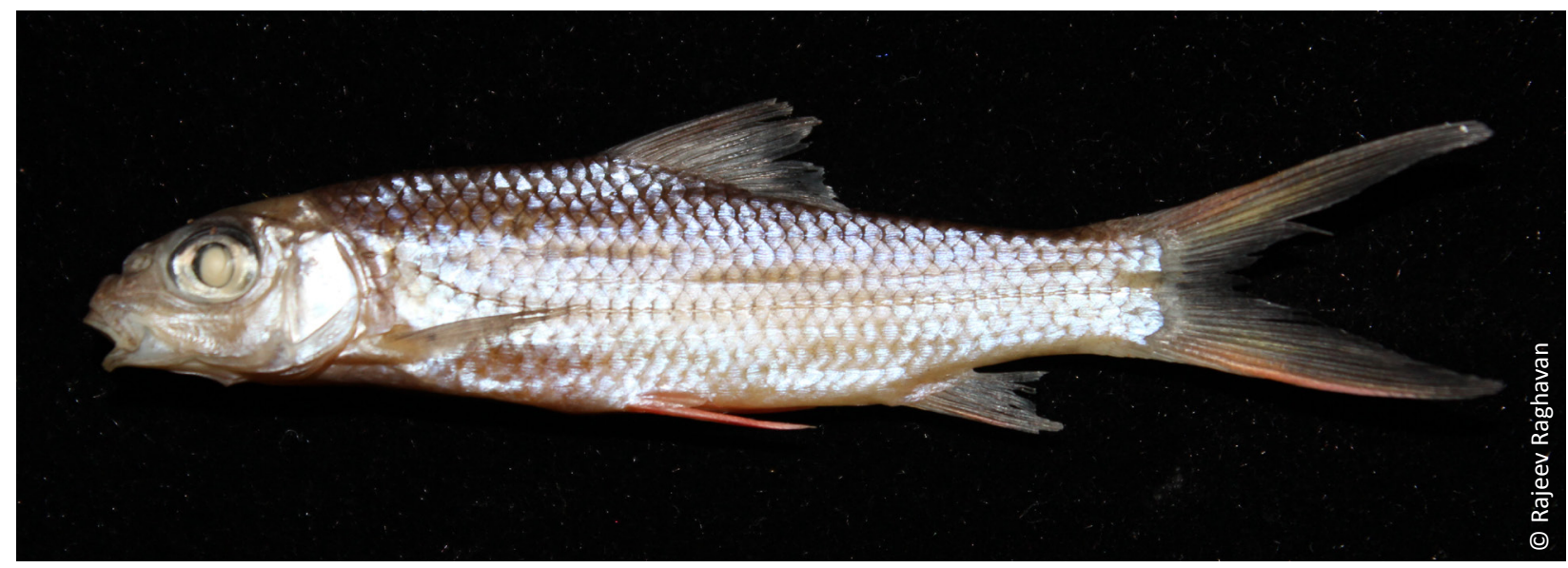

Image 1. Hypselobarbus lithopidos CRG-SAC.2013.3 collected from Chandragiri River, Kerala 


\section{MATERIALS AND METHODS}

Materials examined: Barbus lithopidos Francis Day, BMNH 1889.2.1.559-561, 3 exs., 124.72-171.42 mm SL, South Canara, India (Image 2); Hypselobarbus lithopidos, CRG-SAC.2013.3.1-5, 10.iii.2013; 5 exs., 49.63-60.93 $\mathrm{mm}$ SL, Pallamkode, $12.564^{\circ} \mathrm{N} \& 75.246^{\circ} \mathrm{E}$, Chandragiri River system, Kerala, India, Anvar Ali.

Museum abbreviations: AMS - Australian Museum, Sydney; BMNH - Natural History Museum, London; CRGSAC - Conservation Research Group, St. Albert's College, Kochi; FMNH - Field Museum, Chicago; NMW - Natural History Museum, Vienna; RMNH - Naturalis, Leiden; ZSI-SRS - Zoological Survey of India, Southern Regional Station, Chennai.

Photographs and X-ray: Barbus lithopidos Francis Day, RMNH.PISC.8663B, 1 ex., South Canara, India; Barbus lithopidos, Francis Day, FMNH 2316, 1 ex., South Canara, India; Barbus lithopidos Francis Day, NMW 54256, 1 ex., South Canara, India (Images 2,3).

Taxonomy: We use the generic name Hypselobarbus instead of Gonoproktopterus following Arunachalam et al. (2012) and Yang et al. (2012).

Morphometric data collection: Counts and measurements follow Pethiyagoda et al. (2012). Measurements were taken using a digital calliper to the nearest $0.1 \mathrm{~mm}$. Subunits of body are presented as percent of standard length (SL) and subunits of head are provided as percent of head length $(\mathrm{HL})$.

\section{RESULTS AND DISCUSSION}

Morphometric characters and meristics are presented in Table 2 and Appendix 1 . For detailed description refer to Knight et al. (2013). Values of morphometric characters of the materials that we collected (Table 2) show significant variations from those recorded by Knight et al. (2013). Our specimens were juveniles (49-60 mm), whereas those collected by Knight et al. (2013) and Day (1874) were adults. Raj (1941) mentions that young specimens of $H$. lithopidos (57$90 \mathrm{~mm}$ ) show variations in the morphometric characters and coloration when compared to adults. In addition, it is known that closely related large growing cypriniform fishes, often tend to have an allometric growth pattern (Mina et al. 2005; Patimar \& Farzi 2011), which explains the discrepancy between the morphometric proportions in our study.

Except for the pre-dorsal scales, the meristics of the materials collected by us match those of the syntypes at
Table 1. Records of Hypselobarbus lithopidos from the Western Ghats

\begin{tabular}{|l|l|l|}
\hline Location & Collected by & Reference \\
\hline South Canara $^{1}$ & Francis Day & Day (1874, 1878, 1889) \\
\hline Nimutai (Travancore ${ }^{2}$ ) & Annandale & Jenkins (1909) \\
\hline Trivandrum & S.N. Pillay & Pillay (1929) \\
\hline Trivandrum & S.N. Pillay & John (1936) \\
\hline Coorg (Cauvery River) & Hora & Hora (1937) \\
\hline Nilambur (River Chaliyar) & B.S. Raj & Raj (1941) \\
\hline Bhadravati (River Bhadra) & David & David (1956) \\
\hline Periyar Tiger Reserve & - & Indra \& Remadevi (1990) \\
\hline $\begin{array}{l}\text { Manakkavala (Periyar Tiger } \\
\text { Reserve) }\end{array}$ & R.S. Pillai & Jayaram (1991) \\
\hline Khal River (Maharashtra) & Arunachalam & Arunachalam et al. (2000) \\
\hline Kagina River (Karnataka) & - & Vijaykumar et al. (2008) \\
\hline Bheema River (Karnataka) & - & $\begin{array}{l}\text { Vijaylaxmi \& Vijaykumar } \\
\text { (2011) }\end{array}$ \\
\hline
\end{tabular}

${ }^{1}$ Currently Dakshina Kannada and Udupi District of Karnataka and Kasargod District of Kerala

${ }^{2}$ Currently the region extending from Kanyakumari District of Tamil Nadu to Ernakulam District of Kerala

"East flowing river systems

the Natural History Museum (BMNH), London and those recorded recently by Knight et al. (2013). The pre-dorsal scale count of our materials was 12-13, while those of Knight et al. (2013) and the syntypes/Day's materials at BMNH and AMS are in the range of 13-14 (R. Britz \& R. Pethiyagoda pers. comm). Raj (1941), mentioned that H. lithopidos has a pre-dorsal scale count range of 11-14 based on the observations of both his material (from Nilambur) as well as Day's materials in the Zoological Survey of India, thereby bringing the pre-dorsal scale count of the specimens examined in our study well within range.

Interestingly, not a single individual of $H$. lithopidos has been recorded from the state of Kerala in the last four decades. The last individual recorded from this part of the Western Ghats was from the Periyar Tiger Reserve in 1975 by R.S. Pillai (Jayaram 1991). Since then, several comprehensive ichthyological surveys have been carried out in the Periyar Tiger Reserve resulting in the description of many new species, but no records of $\mathrm{H}$. lithopidos have been made. Although voucher specimens of R.S. Pillai's collection (ZSI.SRS.F.2088; 3 ex. $148-158 \mathrm{~mm}$ ) were deposited, these are currently untraceable (see Knight et al. 2013). Also, previous records of $H$. lithopidos from Kerala with the exception of Raj (1941) do not provide detailed information (especially biometrics) on the materials collected or examined. Raj (1941) recorded a single specimen from Nilambur for 


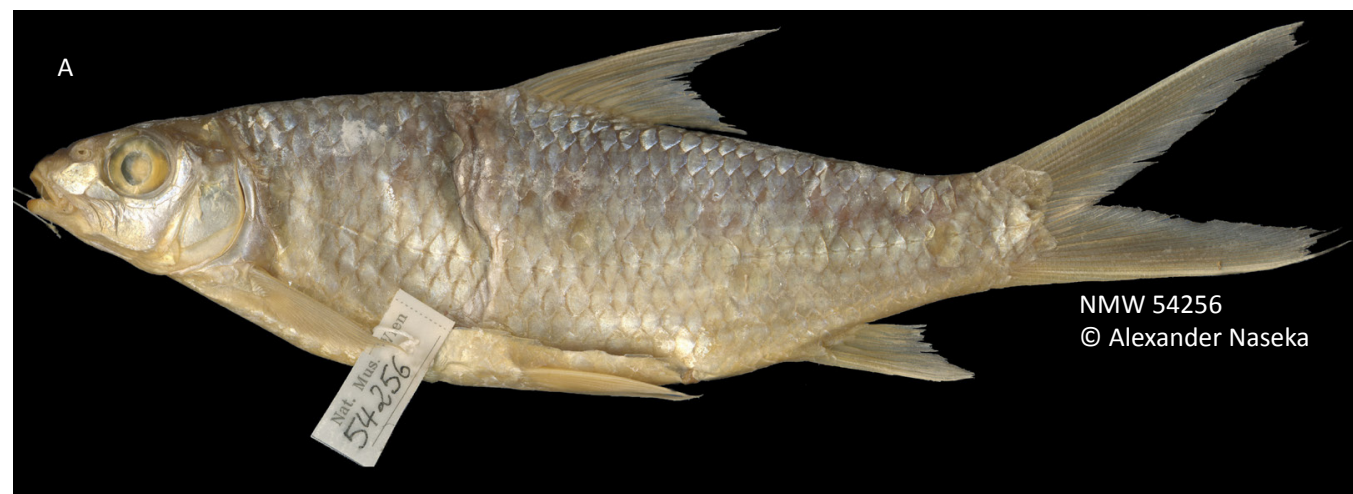

B

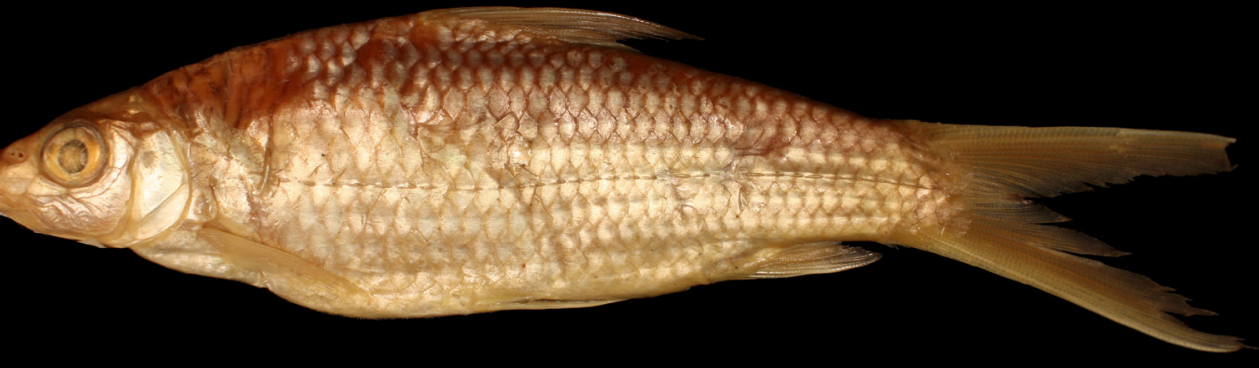

FMNH 2316

(C) Kevin Swagel
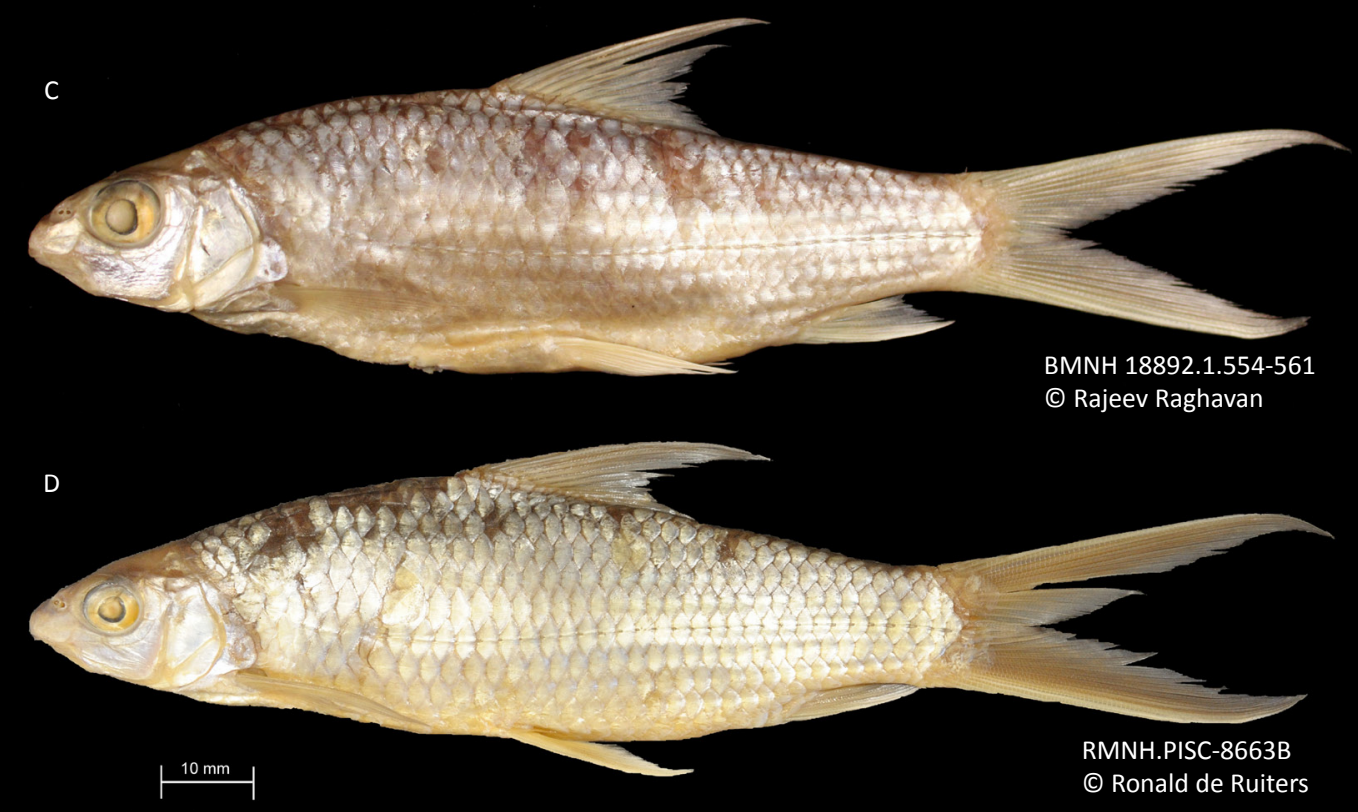

Image 2. Syntypes and/or Day specimens of Hypselobarbus lithopidos

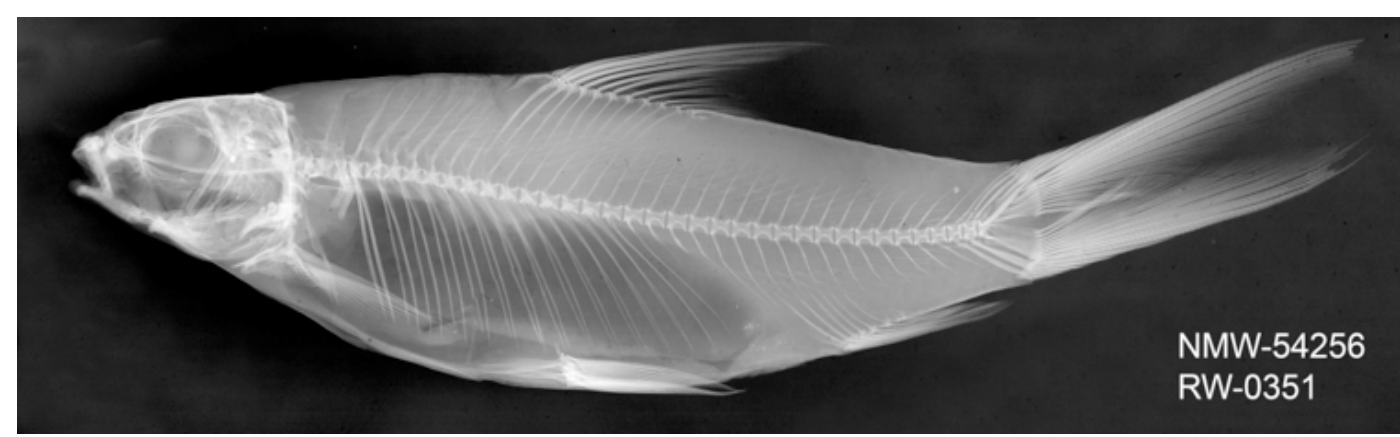

Image 3. X-Ray of a syntype of Hypselobarbus lithopidos 
which he does not provide any biometric details. $\mathrm{He}$ however mentions examining seven specimens of $H$. lithopidos ranging in size from $57-325 \mathrm{~mm} \mathrm{SL}$. It is clear that one of the specimens that he examined $(57 \mathrm{~mm} \mathrm{SL})$ is not a $\mathrm{H}$. lithopidos as the lateral line scale count has been mentioned to be 30 .

Similar to Arunachalam et al. (2012), ichthyological books/field guides from India (for e.g. Tekriwal \& Rao 1999) have also provided misleading photographs on the identity of $H$. lithopidos. Tekriwal \& Rao (1999; $p$ 65) in their book on the ornamental aquarium fish of India provide an image of a barb that they call Gonoproktopterus (= Hypselobarbus) lithopidos. However, the fish in the image has no more than 25 lateral line scales, and therefore is a misidentification. We hope that the images of live specimens as well as those of the type series of $H$. lithopidos provided in Knight et al. (2013) and the current paper will help ichthyologists working in the Western Ghats region to correctly identify $\mathrm{H}$. lithopidos in the future.

The information available at present indicates that $H$. lithopidos occurs in the west flowing Phalguni stream (Kumaradhara-Nethravati river system) and the Chandragiri River in the state of Kerala (Image 4). Both these rivers are part of the erstwhile South Canara from where the species was described by Day (1874). The records further south (earlier records; Image 4) could either be misidentifications, or point to a scenario where the species was probably extirpated from these locations. However, both these scenarios need to be confirmed with future exploratory surveys.

The habitat in Pallamkode, from where we collected specimens of $\mathrm{H}$. lithopidos, consist of many deep pools with intermittent 'run' and 'glide' microhabitats, and supported by high amount of canopy cover. In-stream habitat cover existed in the form of twigs and wooden logs.

Local knowledge of fishers in the Chandragiri River indicate that the species is mostly found in the streams from Sullia in Karnataka to (near) the town of Adoor across the border in Kerala. Fingerlings are especially seen during the months of July to August which might indicate that the species breeds during the south-west monsoons. Our collection of juveniles also indicates that recruitment is taking place, and if on-going threats are curtailed populations of this rare large barb could be stabilized.

Interestingly, extensive surveys in the Kasargod District of Kerala (erstwhile South Canara) including River Chandragiri by Biju (2005) as well as neighbouring basins of Uppala and Manjeshwaram by Biju et al. (1999
Table 2. Morphometric characters of Hyselobarbus lithopidos collected from Chandragiri River, Kerala

\begin{tabular}{|c|c|c|}
\hline Morphometric character & Range $(n=5)$ & Mean+SD \\
\hline Standard Length (SL in $\mathrm{mm}$ ) & $49.6-60.9$ & \\
\hline \multicolumn{3}{|l|}{$\% S L$} \\
\hline Head length (HL) & $26.7-28.5$ & $27.5 \pm 0.6$ \\
\hline Head width & 14. 9-15.5 & $15.12 \pm 0.2$ \\
\hline Dorsal head length & $23.0-24.3$ & $23.67 \pm 0.5$ \\
\hline Pre dorsal length & $48.5-50.3$ & $49.36 \pm 0.6$ \\
\hline Pre anal length & $75.3-77.2$ & $76.26 \pm 0.8$ \\
\hline Pre pelvic length & $51.5-53.2$ & $52.34 \pm 0.6$ \\
\hline Caudal peduncle length & $16.0-17.3$ & $16.75 \pm 0.4$ \\
\hline Caudal peduncle depth & $11.5-11.9$ & $11.70 \pm 0.1$ \\
\hline Body depth & $23.5-25.7$ & $24.62 \pm 0.8$ \\
\hline Body width & $12.9-14.3$ & $13.59 \pm 0.5$ \\
\hline Dorsal fin height & $25.5-29.9$ & $27.80 \pm 1.6$ \\
\hline $\begin{array}{l}\text { Length of stiff portion of last } \\
\text { unbranched ray }\end{array}$ & $20.7-23.3$ & $21.88 \pm 1.2$ \\
\hline Dorsal fin base length & $16.0-19.2$ & $17.79 \pm 1.2$ \\
\hline Pectoral fin length & $19.5-21.5$ & $20.30 \pm 0.8$ \\
\hline Pectoral fin base length & $4.6-4.9$ & $4.78 \pm 0.0$ \\
\hline Pelvic fin length & $19.9-22.8$ & $20.79 \pm 1.1$ \\
\hline Pelvic fin base length & $4.7-5.4$ & $5.07 \pm 0.2$ \\
\hline Anal fin length & $18.2-21.3$ & $19.61 \pm 1.1$ \\
\hline Anal fin base length & $9.1-10.0$ & $9.62 \pm 0.3$ \\
\hline Dorsal-hypural distance & $54.9-57.4$ & $56.19 \pm 1.1$ \\
\hline Post dorsal distance & $36.6-40.4$ & $38.53 \pm 1.6$ \\
\hline Snout length & $9.1-10.0$ & $9.68 \pm 0.4$ \\
\hline \multicolumn{3}{|l|}{$\% \mathrm{HL}$} \\
\hline Snout length & $34.1-36.7$ & $35.23 \pm 1.1$ \\
\hline Post orbital head length & $36.7-40.9$ & $38.99 \pm 1.7$ \\
\hline Head depth & $67.3-74.9$ & $71.50 \pm 2.9$ \\
\hline Eye diameter & $38.0-41.1$ & $39.29 \pm 1.1$ \\
\hline Inter narial width & $18.4-22.5$ & $20.64 \pm 1.5$ \\
\hline Inter orbital width & $24.7-26.2$ & $25.46 \pm 0.6$ \\
\hline Gape width & $21.8-24.6$ & $23.01 \pm 1.0$ \\
\hline \multicolumn{3}{|l|}{$\begin{array}{l}\text { D iii 9; P i } 14 \text {; V i 8; A iii 5; C 1-9-8-1; LI } \\
38 \text { +1; Ltr } 1 \frac{2-6-1-3-1 / 2}{}\end{array}$} \\
\hline \multicolumn{3}{|l|}{ Pre dorsal scales $12-13$} \\
\hline \multicolumn{3}{|l|}{ Vertebrae $34(22+12)^{*}$} \\
\hline *based on material NMW 54256 & & \\
\hline
\end{tabular}

$\mathrm{a}, \mathrm{b})$ did not yield any specimens of $H$. lithopidos. These authors could also not collect $H$. thomassi, known to be the closest resembling congener to $H$. lithopidos (see Knight et al. 2013), thereby eliminating the possibility of a misidentification between the two. 


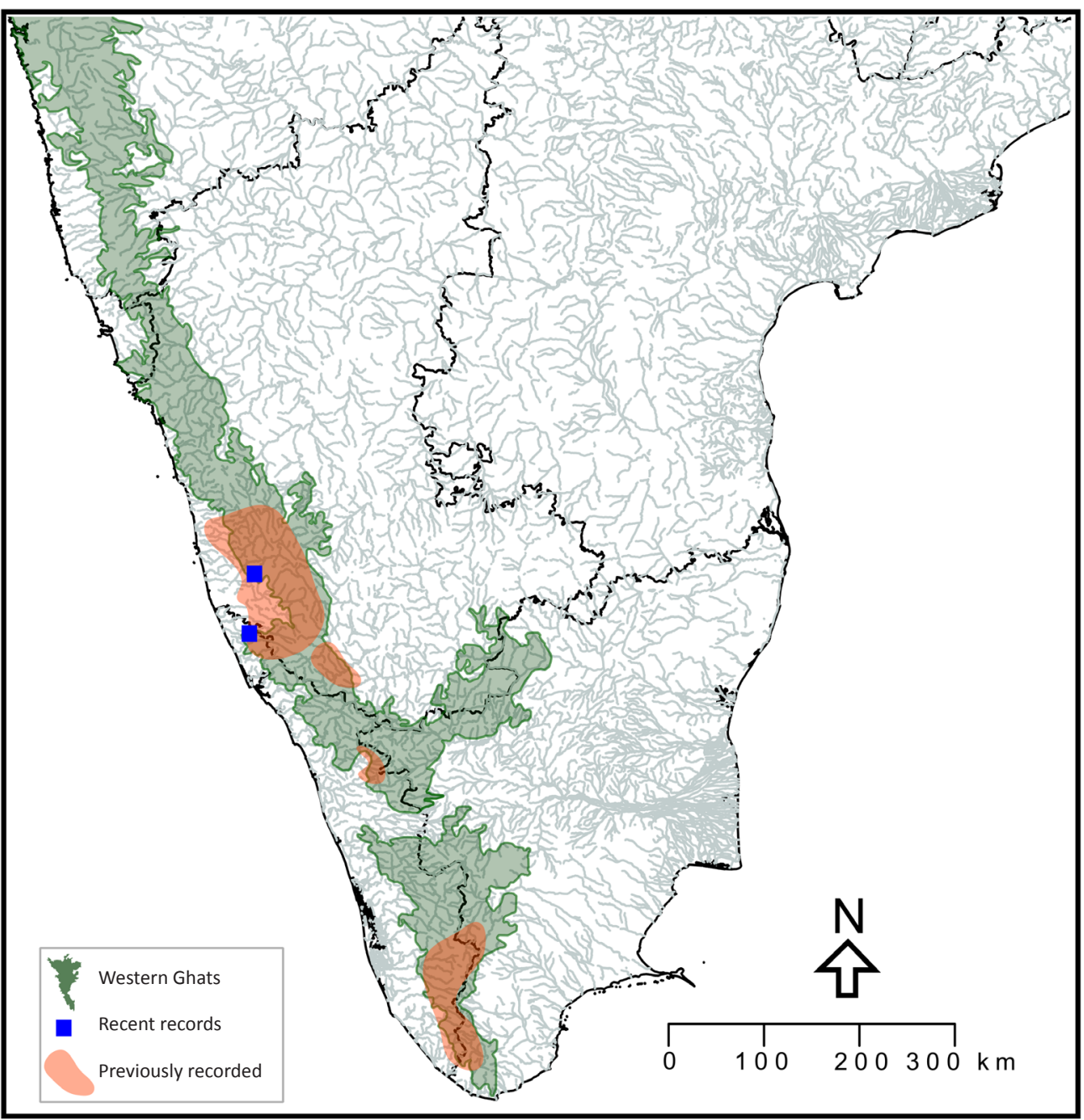

Image 4. Current and previously recorded range of Hypselobarbus lithopidos in the Western Ghats

Dynamiting is a major threat to the species in the streams around Sullia (Karnataka State), where there are many deep pools in which large sized $H$. lithopidos are often seen. Poisoning and electric fishing are also prevalent in this region, especially when the water levels are low. There is also a continuing decline in the quality of habitats due to pollution from domestic sources as well as petroleum related pollution as a result of washing motor vehicles.

There is no targeted fishing for $H$. lithopidos in the Chandragiri River Basin. However, they are often caught as by-catch during aquarium fish collections for two congeneric species, $\mathrm{H}$. jerdoni and $\mathrm{H}$. thomassi. Local aquarium fish collectors reveal that the species is often mixed with consignments of $H$. jerdoni as a filler, since both species look superficially alike in their juvenile stages.

Currently, H. lithopidos has been listed as Data
Deficient (Raghavan \& Ali 2011) with a note that the species could probably be extinct. Additional information from Knight et al. (2013) and the present paper have led to a scenario where the Red List status of the species needs to be revised. The proposed Red List Status of the species has been provided in Appendix 2.

Rediscovery of purportedly extinct and missing species is known to be a non-random process, with the chance of success depending on search effort, search area, time missing and traits known to be associated with extinction risk such as population density and range size (Fisher \& Blomberg 2011). Considering the increasing spate of rediscoveries across several taxa, Scheffers et al. (2011) believe that many species, particularly those known only from type specimens, that are currently thought to have gone 'extinct', remain 'extant', and with continued support for biological surveys, many of these species will be relocated with time. Several recent 
studies on freshwater fishes of the Western Ghats which have reported the rediscovery of 'missing', 'Iong lost' or 'poorly known' species (Dahanukar et al. 2011; Britz et al. 2012; Ali et al. 2013; Knight et al. 2013) are testimony to this.

\section{REFERENCES}

Ali, A., N. Dahanukar, A. Kanagavel, S. Philip \& R. Raghavan (2013) Records of the endemic and threatened catfish, Hemibagrus punctatus from the southern Western Ghats with notes on its distribution, ecology and conservation status. Journal of Threatened Taxa 5(11): 4569-4578. http://dx.doi.org/10.11609/JoTT. o3427.4569-78

Ahmad, S., M. Muralidharan, M. Venkateshwarlu \& M. Arunachalam
(2013). Distribution pattern, endemism, threat status and conservation measures of fishes in the Tunga and Bhadra rivers of Western Ghats, India. Environmental Biology of Fishes 96(10-11): 1245-1256; http://dx.doi.org/10.1007/s10641-011-9915-y

Arunachalam, M., J.A. Johnson, A. Manimekalan, A. Sankaranarayanan \& R. Soranam (2000). Cultivable and ornamental fishes of Western Ghats part of Maharashtra, pp. 217-222. In: Ponniah A.G. \& A. Gopalakrishnan (eds.). Endemic Fish Diversity of Western Ghats. NBFGR-NATP Publication, National Bureau of Fish Genetic Resources, Lucknow, Uttar Pradesh, India.

Arunachalam, M., M. Raja, M. Muralidharan \& R.L. Mayden (2012). Phylogenetic relationships of species of Hypselobarbus (Cypriniformes: Cyprinidae): an enigmatic clade endemic to aquatic systems of India. Zootaxa 3499: 63-73

Biju, C.R. (2005). Habitat and Distribution of Hillstream Fishes of Northern Kerala (north of Palghat Gap). PhD Thesis. Mahatma Gandhi University, Kottayam, India.

Biju, C.R., K.R. Thomas \& C. Ajithkumar (1999a). Freshwater fish distribution in the Manjeshwaram River, Kasargod District, Kerala,

Appendix 1. Morphometric measurements of Hypselobarbus lithopidos collected during the present study

\begin{tabular}{|c|c|c|c|c|c|}
\hline & $\begin{array}{l}\text { CRG-SAC. } \\
2013.3 .1\end{array}$ & $\begin{array}{l}\text { CRG-SAC. } \\
\text { 2013.3.2 }\end{array}$ & $\begin{array}{l}\text { CRG-SAC. } \\
2013.3 .3\end{array}$ & $\begin{array}{l}\text { CRG-SAC. } \\
2013.3 .4\end{array}$ & $\begin{array}{l}\text { CRG-SAC. } \\
2013.3 .5\end{array}$ \\
\hline Standard Length (SL) in mm & 59.6 & 51.6 & 53.3 & 49.6 & 60.9 \\
\hline \multicolumn{6}{|l|}{$\%$ SL } \\
\hline Head length (HL) & 27.0 & 27.3 & 27.8 & 28.5 & 26.8 \\
\hline Head width & 14.9 & 15.5 & 14.9 & 15.1 & 15.2 \\
\hline Dorsal head length & 23.4 & 24.4 & 23.6 & 24.0 & 23.0 \\
\hline Pre dorsal length & 49.2 & 50.3 & 49.8 & 48.6 & 49.1 \\
\hline Pre anal length & 75.3 & 76.5 & 77.1 & 75.4 & 77.2 \\
\hline Pre pelvic length & 52.1 & 52.8 & 51.5 & 52.1 & 53.2 \\
\hline Caudal peduncle length & 16.8 & 17.3 & 17.0 & 16.0 & 16.6 \\
\hline Caudal peduncle depth & 11.7 & 11.8 & 11.5 & 12.0 & 11.6 \\
\hline Body depth & 23.5 & 24.5 & 24.2 & 25.3 & 25.7 \\
\hline Body width & 13.5 & 13.0 & 14.0 & 13.2 & 14.3 \\
\hline Dorsal fin height & 25.5 & 28.1 & 28.5 & 27.0 & 29.9 \\
\hline $\begin{array}{l}\text { Length of stiff portion of last } \\
\text { unbranched ray }\end{array}$ & 20.7 & 23.3 & 23.1 & 21.2 & 21.0 \\
\hline Dorsal fin base length & 18.3 & 16.8 & 18.6 & 16.1 & 19.2 \\
\hline Pectoral fin length & 19.8 & 20.8 & 19.8 & 21.5 & 19.5 \\
\hline Pectoral fin base length & 4.8 & 4.8 & 4.7 & 4.8 & 4.9 \\
\hline Pelvic fin length & 20.3 & 19.9 & 20.3 & 22.8 & 20.7 \\
\hline Pelvic fin base length & 5.2 & 5.0 & 4.7 & 5.1 & 5.4 \\
\hline Anal fin length & 18.3 & 19.7 & 19.2 & 21.3 & 19.7 \\
\hline Anal fin base length & 10.0 & 9.3 & 9.1 & 9.7 & 9.9 \\
\hline Dorsal hypural distance & 57.4 & 56.5 & 55.1 & 57.0 & 54.9 \\
\hline Post dorsal distance & 40.4 & 38.5 & 37.4 & 36.6 & 39.8 \\
\hline Snout length & 9.3 & 10.0 & 10.0 & 10.0 & 9.1 \\
\hline \multicolumn{6}{|l|}{$\% \mathrm{HL}$} \\
\hline Snout length & 34.2 & 36.7 & 36.0 & 35.2 & 34.2 \\
\hline Post orbital head length & 39.5 & 40.9 & 38.9 & 36.7 & 49.7 \\
\hline Head depth & 72.0 & 74.9 & 70.1 & 67.3 & 73.1 \\
\hline Eye diameter & 38.1 & 41.2 & 38.8 & 39.4 & 39.1 \\
\hline Inter narial width & 20.2 & 21.6 & 20.4 & 18.5 & 22.5 \\
\hline Inter orbital width & 24.7 & 26.2 & 24.9 & 25.3 & 26.2 \\
\hline Gape width & 22.7 & 22.9 & 24.7 & 21.9 & 23.0 \\
\hline
\end{tabular}


Appendix 2

Proposed Red List Status for Hypselobarbus lithopidos

CURRENT STATUS: DATA DEFICIENT (DD)

Proposed Status: ENDANGered (EN) B1ab(ii,iii,v)+2ab(ii,iii,v)

Taxonomy

SCIENTIFIC NAME: Hypselobarbus lithopidos

SPECIES AUTHORITY: Day (1874)

COMMON NAME: Canarese barb

SYNONYMS: Barbus lithopidos, Puntius lithopidos, Gonoproktopterus lithopidos

TAXONOMIC NOTES: There is considerable taxonomic ambiguity on the generic status of this species, having been placed in Barbus (Day 1874), Puntius (Jayaram 1981), Gonoproktopterus (Jayaram 2010; Pethiyagoda et al. 2012) and Hypselobarbus (Arunachalam et al. 2012; Yang et al. 2012). The most recent paper (Yang et al. 2012) has placed the species within the genus Hypselobarbus. However, none of these papers (Arunachalam et al. 2012; Pethiyagoda et al. 2012; Yang et al. 2012) discuss the ambiguity surrounding the type species of the genus Hypselobarbus (i.e. H. mussullah) and the related taxonomic issues regarding the validity of the genus.

\section{Geographic range}

RANGE DESCRIPTION: Endemic to the southern region of the Western Ghats (Dahanukar et al. 2004). Currently the species is known to be confined to two river basins in its type locality (South Canara), the Phalguni River in Karnataka and the Chandragiri River flowing through both Karnataka and Kerala (present study; Knight et al. 2013). Although literature indicates that the historic range of the species could have extended till southern Kerala, there are no voucher materials to confirm this. The estimated (approximate) current Extent of Occurrence (EOO) is no more than $1000 \mathrm{~km}^{2}$ and current (approximate) Area of Occupancy (AOO) no more than $100 \mathrm{~km}^{2}$

LOCATIONS: Information available at present indicates that the species is found in two locations as defined by the IUCN Red List of Threatened Species (IUCN 2001). The two locations are Sullia in Chandragiri River, and streams near the town of Iruvail in Phalguni River. Both these sites are located in two distinct drainages.

DISTRIBUTION: India (States of Karnataka and Kerala)

RANGE MAP: see Image 4

\section{Habitat and Ecology}

HABITAT AND ECOLOGY: Known to attain $600 \mathrm{~mm}$ in length. Inhabits fast flowing streams, where they are found mostly in deep pools.

SYSTEMS: Freshwater

\section{Threats}

MAJOR THREATS: Destructive fishing practices such as dynamiting, poisoning and electric fishing are the major threats in the Chandragiri River Basin of Karnataka State, India (current study). Dynamiting and other destructive forms of fishing, as well as pollution from multiple sources threaten populations in one of the location (Sullia), sand mining and damming of the stream threaten populations in the second location (near Iruvail in Phalguni River).

\section{Population}

POPULATION: No information on the population status. Local knowledge of fishers in the Chandragiri River Basin indicates that the numbers are fewer when compared to its congener, $H$. jerdoni.

POPULATION TREND: Decreasing

\section{Assessment Information}

Red List category and criteria: Endangered; B1ab(ii,iii,v)+2ab(ii, iii,v)

JUSTIFICATION: Hypselobarbus lithopidos is assessed as Endangered because of its restricted distribution to two locations in the Chandragiri and Phalguni rivers in the southern Western Ghats. The current extent of occurrence (EOO) is less than $5000 \mathrm{~km}^{2}$ and the area of occupancy is less than $500 \mathrm{~km}^{2}$. There is also a continuing decline in the quality of the remaining habitats due to pollution and destructive fishing practices. Juveniles of the species are also threatened as a result of bycatch

\section{Conservation}

CONSERVATION ACTION: The species has not been recorded from any protected area as yet. No conservation actions are also currently in place. The project on 'Lost fishes of the Western Ghats' is involved in research, education and awareness on poorly known species of the region including $\mathrm{H}$. lithopidos. Increased survey efforts are needed in other river systems of southern Karnataka and northern Kerala (in around the type locality: South Canara) to confirm whether undiscovered populations exist. Education and awareness programs need to be carried out in close cooperation with the Fisheries Department as well as local self governments (Panchayath) in the South Canara region.

India. Journal of the Bombay Natural History Society 96(1): 159-161. Biju, C.R., K.R. Thomas \& C. Ajithkumar (1999b). Distribution of freshwater fishes in the Uppala River, Kasargod District, Kerala. Journal of the Bombay Natural History Society 96(2): 334-335.

Britz, R., A. Ali, K.K. Kumar, S. Philip \& R. Raghavan (2012). First record from the wild of Carinotetraodon imitator in Peninsular India (Teleostei: Tetraodontiformes: Tetraodontidae). Ichthyological Exploration of Freshwaters 23(2): 105-109.

Chapgar, B.F. \& R. Manakadan (Editors) (2000). Ecology of Hill Streams of Western Ghats with Special Reference to Fish Community. US Fish and Wildlife Service \& Bombay Natural History Society, 203pp.

Dahanukar, N., M. Diwekar \& M. Paingankar (2011). Rediscovery of the threatened Western Ghats endemic sisorid catfish, Glyptothorax poonaensis (Teleostei: Siluriformes: Sisoridae). Journal of Threatened Taxa 3(7): 1885-1898; http://dx.doi.org/10.11609/JoTT. 02663.1885-98

Dahanukar, N., R. Raut \& A. Bhat (2004). Distribution, endemism and threat status of freshwater fishes in the Western Ghats of India. Journal of Biogeography 31(1): 123-136; http://dx.doi. org/10.1046/j.0305-0270.2003.01016.x

David, A. (1956). Studies on pollution of Bhadra River fisheries at Bhadravti (Mysore state) with industrial effluents. Proceedings of the National Institute of Science, India 22: 132-160.

Day, F. (1874). On some new or little-known fishes of India. Proceedings 
of the Zoological Society of London 1873(3): 704-710.

Day, F. (1878). The Fishes of India; Being a Natural History of the Fishes Known to Inhabit the Seas and Fresh Waters of India, Burma, and Ceylon. Quaritsch, London, i-xx, 553-778, pls. 139-195.

Day, F. (1889). Fishes. In: Blanford, W.T. (ed). The Fauna of British India Including Ceylon and Burma. Taylor \& Francis, London. v. 1: 1-xviii $+1-548 \mathrm{pp}$.

Easa, P.S. \& S.C. Basha (1995). A survey of the habitat and distribution of stream fishes in the Kerala part of Nilgiri Biosphere Reserve. Kerala Fisheries Research Institute No. 104.

Fisher, D.O. \& S.P. Blomberg (2011). Correlates of rediscovery and the detectability of extinction in mammals. Proceedings of the Royal Society B-Biological Sciences 278(1708): 1090-1097; http://dx.doi. org/10.1098/rspb.2010.1579

Hora, S.L. (1937). Notes on fishes in the Indian Museum - XXVIII. On three collections of fish from Mysore and Coorg, south India. Records of the Indian Museum 39(1): 5-28.

IUCN (2001). IUCN Red List Categories and Criteria: version 3.1 IUCN Species Survival Commission. IUCN, Gland, Switzerland and Cambridge, UK.

Indra, T.J. \& K.R. Devi (1990). On a small collection of fish from Thekkady Wildlife reserve, Western Ghats. Records of the Zoological Survey of India 87 (3): 249-257

Jayaram, K.C. (1991). Revision of the Genus Puntius Hamilton from the Indian region (Pisces: Cypriniformes, Cyprinidae, Cyprininae). Records of the Zoological Survey of India Occasional Paper 135: 1-178.

Jayaram, K.C. (1981). The Freshwater Fishes of India, Pakistan, Bangladesh, Burma and Sri Lanka - A Handbook. Zoological Survey of India. i-xxii + 1-475, Pls. 1-13

Jayaram, K.C. (2010). The Freshwater Fishes of The Indian Region. Revised $2^{\text {nd }}$ Edition. Narendra Publishing House, 616pp+xxxixpls

Jenkins, J.T. (1909). Fish from Travancore and Cochin. Records of the Indian Museum 3: 287-293.

John, C.C. (1936). Freshwater fish and fisheries of Travancore. Journal of the Bombay Natural History Society 35: 132-157.

Knight, J.D.M., A. Rai \& R.K.P. D'souza (2013). Re-description of Hypselobarbus lithopidos (Teleostei: Cyprinidae), based on its rediscovery from the Western Ghats, India, with notes on $H$. thomassi. Journal of Threatened Taxa 5(13): 4734-4742; http:// dx.doi.org/10.11609/JoTT.o3602.4734-42

Kurup, B.M., K.V. Radhakrishnan \& T.G. Manojkumar (2004). Biodiversity Status of Fishes Inhabiting Rivers of Kerala (South India)
With Special Reference to Endemism, Threats and Conservation Measures. In: Welcomme, R.L \& T. Petr (eds.). Proceedings of the Second International Symposium on the Management of Large Rivers for Fisheries 2 (LARS2): 310p. Cambodia.

Mina, M.V., A.N. Mironovsky \& Y. Dgebuadze (1996). Lake Tana large barbs: phenetics, growth and diversification. Journal of Fish Biology 48(3): 383-404; http://dx.doi.org/10.1111/j.1095-8649.1996. tb01435.x

Patimar, R. \& S. Farzi (2011). Life history and other biological traits of the trout barb Capoeta trutta in the River Meymeh (western Iran). Folia Zoologica 60(2): 153-158.

Pethiyagoda, R., M. Meegaskumbura \& K. Maduwage (2012). A synopsis of the South Asian fishes referred to Puntius (Pisces: Cyprinidae). Ichthyological Exploration of Freshwaters 23(1): 69-95.

Pillai, R.S.N. (1929). A list of fishes taken in Travancore from 19011915 Journal of the Bombay Natural History Society 30: 111-126

Raghavan, R. \& A. Ali (2011). Hypselobarbus lithopidos. In: IUCN Red List of Threatened Species. Version 2011.2. www.iucnredlist.org. Downloaded on 25 May 2013.

Raj, B.S. (1941). Two new cyprinid fishes from Travancore, South India with remarks on Barbus (Puntius) micropogon Cuv \& Val. Records of the Indian Museum 43(3): 233-256.

Scheffers, B.R., D.L. Yong, J.B.C. Harris, X. Giam \& N.S. Sodhi (2011). The World's Rediscovered Species: Back from the Brink? PLoS ONE 6(7): e22531. http://dx.doi.org/10.1371/journal.pone.0022531

Tekriwal, K.L. \& Rao, A.A. (1999). Ornamental Aquarium Fish of India. Kingdom Books, Waterlooville, England, 144pp.

Thomas, R.K. (2004). Habitat and Distribution of Hillstream Fishes of Southern Kerala (South of Palghat Gap). PhD Thesis. Mahatma Gandhi University, Kottayam, India.

Vijaylaxmi, C. \& K. Vijaykumar (2011). Biodiversity of fish fauna of the Bheema River in Gulbarga District of Karnataka. The Ecoscan 5 (1\&2): $21-25$

Vijaykumar, K., C. Vijaylaxmi \& Z. Parveen (2008). Ichthyofaunal diversity of Kagina River in Gulbarga District of Karnataka. The Ecoscan 2(2): 161-163.

Yang, L., M.V Hirt, T. Sado, M. Arunachalam, R. Manickam, K.L. Tang, A.M. Simons, H-H. Wu, R.L. Mayden \& M. Miya (2012). Phylogenetic placements of the barbin genera Discherodontus, Chagunius, and Hypselobarbus in the subfamily Cyprininae (Teleostei: Cypriniformes) and their relationships with other barbins. Zootaxa 3586: 26-40. 